\title{
Keputusan bentuk visual dalam mendesain self service kiosk
}

\author{
Rafi Ihsandiyumna ${ }^{1 *}$, Andry Masri² \\ ${ }^{1,2}$ Jurusan Desain Produk, Fakultas Seni Rupa dan Desain, Institut Teknologi Nasional, Bandung Indonesia
}

\begin{abstract}
Significant changes have occurred in the past decades from analogue or manual technology to digital technology which caused many industries to adapt or even transition to it. One of a product commodity which is the result of innovation caused by this change is self-service technology (SST). Currently, there aren't so many industries of SSTs in Indonesia, but the concept is still feasible because it has characteristics that have high selling value and facilitate activities in commercial industry in general. This literature examines the important aspects which take effect and need to be considered in SST visual form decision making. The purpose of this research is to produce SST design through formalistic approach also as a tool for the analysis process in space, human, and business aspects. This research generates a product design which has harmony in the interaction with its surrounding objects' visual characteristics.
\end{abstract}

Key words: innovation, self-service technology, formalistic, visual form decision

\begin{abstract}
Abstrak
Beberapa dekade terakhir terjadi perubahan yang sangat signifikan dari teknologi analog/manual menjadi teknologi digital yang menyebabkan banyak industri beradaptasi atau bahkan bertransisi pada hal tersebut. Salah satu jenis komoditas produk yang merupakan inovasi akibat perubahan ini adalah Self-Service Technology (SST). Saat ini industri SST di Indonesia belum terlalu banyak, namun konsepnya tetap layak untuk diteliti karena memiliki peluang untuk membawa nilai baru pada kegiatan dalam industri komersial secara umum. Tulisan ini membahas aspek-aspek penting yang berpengaruh dan perlu diperhatikan pada pengambilan keputusan visual dari desain SST. Tujuan dari penelitian ini adalah menghasilkan desain SST melalui pendekatan formalistik termasuk sebagai perangkat untuk proses analisis terhadap aspek ruang, manusia, dan bisnis. Penelitian ini menghasilkan desain produk dengan kualitas visual yang memiliki keselarasan dengan objek di sekitarnya.
\end{abstract}

Kata kunci: inovasi, self-service technology, formalistik, keputusan bentuk visual

\section{Pendahuluan}

Pada masa ini percepatan pertumbuhan industri terjadi dengan cepat menyebabkan semakin ketatnya persaingan. Pada era disrupsi ini, industri harus melakukan terobosan melalui kegiatan research \& development baik dari sisi teknologi, pemasaran, maupun desain. Hal yang sama harus dilakukan juga untuk industri lain seperti jasa.

Self-service technology (SST) merupakan teknologi yang memungkinkan pelanggan untuk dapat menggunakan sebuah perangkat secara independen tanpa berinteraksi dengan, atau dibantu oleh, pekerja (Curran \& Meuter, 2005). Penggunaan SST biasanya bertujuan untuk meningkatkan pelayanan, memberi pengalaman yang unik pada pelanggan, menambah efisiensi dan efektifitas pengelolaan sumber daya, bahkan dapat juga sebagai upaya untuk memberikan nilai lebih pada persaingan.

SST merupakan produk yang memiliki unsur teknologi yang dominan, akan tetapi proses pembuatan sebuah SST tidak lepas dari tanggung jawab profesi desainer produk untuk menghubungkan teknologi tersebut dengan manusia sebagai pemakai. Terlepas dari penekanan yang terjadi pada keputusan objek desain, aspek visual setidaknya merupakan satu faktor yang harus diputuskan oleh desainer ketika mengajukan sebuah usulan desain (Masri, 2010).

Cinemaxx merupakan salah satu jejaring bioskop yang banyak dijumpai di Indonesia. Pada era dimana

\footnotetext{
* Corresponding author, e-mail : rafi.ihsandi@gmail.com
} 
popularitas perfilman yang semakin tumbuh pesat seperti saat ini, bioskop seringkali mengalami hightraffic pada film-film box office. Pada bagian penjualan tiket sering terjadi antrian, walaupun tiket bioskop sudah dapat dibeli secara online, namun penonton yang ingin masuk ke dalam teater tetap harus mencetak tiketnya terlebih dahulu. Khusus pada contoh kasus Cinemaxx yang belum memiliki SST, antrian pencetakan tiket kerap bercampur dengan antrian pembelian.

Sebagai bidang yang memberikan solusi dalam bentuk visual, desainer harus mempertimbangkan faktor ini sebagai sesuatu yang bersifat primer karena pada dasarnya pengguna akan berhubungan dengan produk secara visual (De Noblet, 1993). Pendekatan formalistik dalam studi desain merupakan pendekatan yang memiliki capaian benar-tidaknya suatu bentuk visual. Pendekatan formalistik dapat menjadi salah satu cara untuk membantu proses membuat keputusan bentuk visual dalam desain. Pendekatan formalistik merupakan sebuah upaya untuk menjadikan hal-hal mengenai bentuk visual yang walaupun sebenarnya bersifat kualitatif dan subjektif menjadi baku.

"Usaha desainer dalam melakukan olah rupa melalui pendekatan formalistik dilakukan agar keputusan-keputusan kualitas visual yang dapat dianalisis, ditelusuri. Sedangkan hasil dari keputusan tersebut tetap bersifat kontekstual dan subjektif. Kesadaran tentang permasalahan ini perlu dilakukan sejak dini, karena walaupun terdapat usaha untuk 'mematematiskan' kualitas visual, tetap saja penilaian terhadap kualitas visual tetap subjektif." (De Noblet, 1993)

Dalam pendidikan dasar desain kerap diajarkan mengenai unsur desain - titik, garis, bidang, warna, tekstur; serta prinsip desain - harmoni, kesatuan, keseimbangan, proporsi, irama, dan gerak dan arah. Formalistik merupakan alat untuk menelusuri dan menganalisis kualitas visual sebuah objek menggunakan unsur dan prinsip desain, hal tersebut yang membuat kualitas visual yang bersifat subjektif menjadi baku, dapat didefinisikan, dan dapat diukur.

Sebuah produk tidak lepas dari aspek dimana produk itu digunakan dan ditempatkan. Sebuah produk yang memiliki kualitas baik bisa jadi tidak tidak terlihat atau bahkan bisa mengganggu saat produk tersebut diletakkan pada tempat yang tidak sesuai.

Aspek manusia juga berpengaruh pada bagaimana produk yang didesain akan digunakan, sebab pengguna dari produk ini adalah manusia. Selain faktor ergonomi yang jelas hubungannya dengan manusia ada faktor lain yang perlu dipertimbangkan, contohnya seperti faktor budaya maupun faktor kebiasaan. Sebuah desain yang terlalu asing akan menimbulkan kesenjangan terhadap pengguna, hal ini akan menyebabkan menurunnya kualitas interaksi produk terhadap pengguna.

Kemudian desain produk akan selalu berhubungan dengan bisnis. Produk yang didesain tanpa keberadaan sebuah bisnis tidak layak untuk disebut sebagai produk industri. Telah diteliti oleh banyak pakar bahwa kehadiran desain pada suatu proses produksi dapat meningkatkan kualitas produk dan akan menghasilkan keuntungan yang lebih besar dibandingkan tidak menggunakan desain.

"Every $£ 1$ spent on design can give you over £20 in increased revenue, and $£ 4$ in increased profit. And if you want to sell to new markets, that same 11 can turn into $£ 5$ in increased exports” (Design Council, 2007).

Berdasarkan ketiga aspek tersebut maka desainer menyimpulkan untuk melakukan analisis formalistik terhadap ketiga faktor tersebut. Kemudian hasil analisis tersebut akan menghasilkan sebuah deskripsi karakteristik visual. Karakteristik visual tersebut dijadikan acuan mengimplementasikan konsep desain pada pembuatan alternatif desain. Dengan cara itu diharapkan akan tercipta desain produk self-service kiosk dengan pencapaian bentuk yang menguntungkan, yang pada aspek ini memiliki definisi selaras dengan objek-objek visual yang berada di sekelilingnya dan tidak menjadi gangguan pada tempat tersebut, sehingga kehadiran objek dapat memberikan reaksi emosional yang positif (Masri, 2010)..

\section{Bahan dan metode}

Hal yang sering dialami oleh desainer adalah tidak adanya satu acuan untuk memulai proses analisis dalam pengolahan aspek visual. Oleh karena itu penggunaan analisis formalistik dapat dijadikan suatu pegangan untuk melakukan pengambilan keputusan dan melakukan evaluasi terhadap aspek visual. Berdasarkan hal tersebut maka tugas desainer dapat disimpulkan sebagai (1) analisis unsur visual dan perseptual terhadap suatu objek yang ingin dipinjam karakteristiknya. (2) Mempertimbangkan unsur visual formal mana sajakah yang akan dipilih, dan dianggap tepat. (3) Menghasilkan alternatif dengan mempertimbangkan seberapa banyak unsur-unsur formal tersebut akan digunakan, dan (4) Melakukan evaluasi apakah suatu komposisi telah mencapai nilai optimal. 
Unsur-unsur formal yang dapat dipertimbangkan dalam penyusunan analisis ini menggunakan pendekatan formalistik seperti tampak pada Tabel 1. Tahap pertama adalah menentukan objek-objek yang akan dipinjam karakteristik visualnya. Berdasarkan objek-objek tersebut maka dilakukan analisis visual melalui pendekatan formalistik secara satu per satu. Maka akan dihasilkan beragam deskripsi karakteristik visual berdasarkan hasil analisis. Desainer melakukan pertimbangan mengenai unsur visual formal manakah yang perlu dipilih berdasarkan seluruh hasil analisis. Unsur visual formal yang dipilih harus dianggap menguntungkan jika diimplementasikan pada produk yang didesain. Seluruh hasil pertimbangan itu kemudian disatukan menjadi sebuah kesimpulan imageboard yang menjelaskan seluruh unsur visual formal yang dianggap menguntungkan untuk diimplementasikan pada desain berdasarkan analisis yang dilakukan.

Proses sketsa alternatif dilakukan berdasarkan kesimpulan analisis yang dibuat. Tiap-tiap alternatif harus memiliki pertimbangan karakteristik visual yang dijadikan acuan. Setelah alternatif desain dihasilkan, maka desainer dan pemberi tugas melakukan diskusi tentang alternatif mana saja yang dinilai terbaik dari alternatif lainnya berdasarkan pertimbangan keuntungan karakteristik visual, ukuran produk, dan karakteristik produksi. Diskusi tersebut kemudian menghasilkan sebuah preliminary design yang kemudian dilanjutkan pada pembuatan prototype produk.

Objek yang diteliti dalam penelitian ini adalah bioskop Cinemaxx dan Tritek sebagai industri yang dipercayakan untuk membuat mesin self-service. Saat ini telah sangat banyak bermunculan aplikasi online seperti MTix, Go-Tix, Tix.id, yang berguna untuk membeli tiket nonton di bioskop. Hal tersebut sangat menguntungkan karena terdapat efisiensi dimana masyarakat tidak perlu lagi antri panjang, khususnya ketika munculnya film yang dianggap sebagai pop culture dan digilai oleh masyarakat, contohnya seperti "Avengers: Infinity War" yang muncul pada bulan April 2019.

Tabel 1. Unsur-unsur Formal

\begin{tabular}{ll}
\hline \multicolumn{1}{c}{ Unsur Visual } & \multicolumn{1}{c}{ Unsur Perseptual } \\
\hline Titik & Harmoni \\
Garis & Kesatuan \\
Massa/Ruang & Keseimbangan \\
Warna & Intensitas \\
Tekstur & Ukuran dan Proporsi \\
& Irama \\
& Arah dan Gerak \\
\hline
\end{tabular}

(sumber: Strategi Visual, (2010))

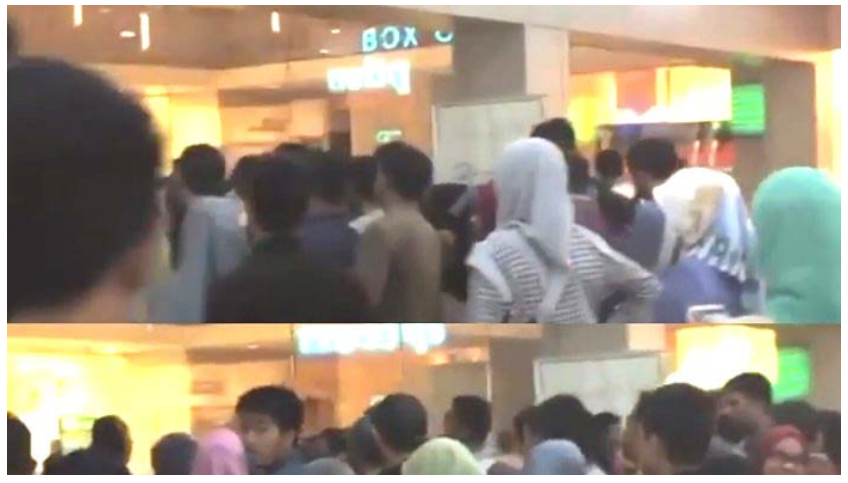

Gambar 1. Antrian penonton “Avengers: Infinity War” (sumber: tribunnews.com)

Namun sayangnya berbanding terbalik dengan fungsi aplikasi pembelian tiket online yang seharusnya mempermudah masyarakat sehingga tidak perlu mengantri untuk pembelian tiket menonton, masyarakat tetap harus mengantri hingga keluar bioskop, contohnya seperti pada Gambar 1.

\section{Hasil dan pembahasan}

Terdapat beberapa unsur penting saat mendesain sebuah self-service kiosk, beberapa unsur ini menjadi hal yang menentukan dalam mengambil keputusan bentuk pada sebuah self-service kiosk. Penulis telah menggolongkan unsur-unsur tersebut menjadi tiga kategori berdasarkan urgensinya untuk dipenuhi. Primer - spesifikasi komponen, software, maintenance \& thermal design, dan estetika; sekunder - ergonomi, desain interface, dan durabilitas; tersier graphic messaging.

Pada studi kasus perancangan ini, proses desain didahului oleh ketetapan engineering, termasuk fungsi dari produk, konsep dasar, dan konfigurasi dasar dari produk self-service kiosk yang akan dijadikan objek kajian. Produk self-service kiosk yang didesain adalah Cinema Ticket Kiosk, yaitu sebuah kiosk yang memungkinkan pengguna untuk melakukan pembelian tiket bioskop melalui produk, bukan dilayani seperti biasanya. Kiosk ini dilengkapi juga dengan beberapa fungsi lain, seperti melihat jadwal film, memilih film, memilih tempat duduk, melakukan pembayaran dengan kartu membership/debit/kredit, memindai barcode dari smartphone, dan mencetak tiket. Seluruh fungsi tersebut menyebabkan adanya tuntutan komponen elektronik apa saja yang diperlukan sehingga dapat dihasilkan konfigurasi komponen seperti tampak pada Gambar 2. 

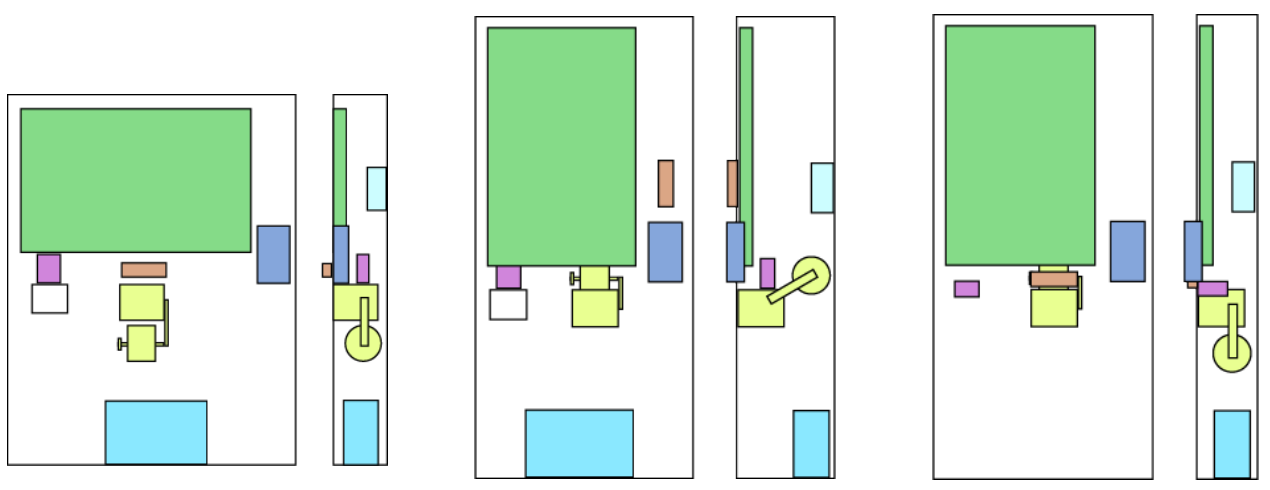

Gambar 2. Konfigurasi Dasar SST

Berdasarkan alternatif konfigurasi yang dihasilkan, dipilih konfigurasi komponen yang kedua (tengah), dengan pertimbangan bahwa konfigurasi tersebut memiliki nilai optimal dari pertimbangan ukuran, interface, dan compactibility dari produk yang didesain. Ketetapan terhadap konfigurasi dasar tersebut dijadikan acuan untuk tahapan selanjutnya baru proses desain yaitu tahap pengolahan visual.

Pada proyek desain ini terdapat dua stakeholder yaitu perusahaan produsen dan klien yang memesan produk. Perusahaan produsen pada proyek ini adalah Tritek, penghasil self-service kiosk dalam berbagai bentuk dan fungsi sesuai kebutuhan klien. Pada kesempatan kali ini Tritek bekerjasama dengan sebuah klien yang memiliki perusahaan di bidang jasa penayangan film yaitu Cinemaxx, sebuah jaringan bioskop yang cabangnya tersebar di seluruh Indonesia.
Produk yang dirancang akan diletakkan pada lobby Cinemaxx sebagai alternatif pembelian dan pencetakan tiket bioskop. Terhadap hal ini dilakukan analisis formalistik pada interior dari bioskop-bioskop Cinemaxx untuk mendapatkan karakteristik visual yang ada pada interior Cinemaxx. Upaya ini dilakukan agar produk yang didesain dapat membawa sebagian karakteristik visual dari objek sekitarnya, sehingga dapat tercipta keselarasan terhadap tempat dimana produk ini diletakkan.

Dari beberapa contoh suasana interior Cinemaxx yang penulis pilih seperti yang tampak pada Gambar 3 , penulis lakukan analisis hingga menghasilkan beberapa kesimpulan mengenai unsur visual dominan yang terdapat pada interior tersebut, yaitu (1) Didominasi oleh bidang yang dibentuk oleh garis lurus yang disusun secara beraturan mengikuti pola tertentu.

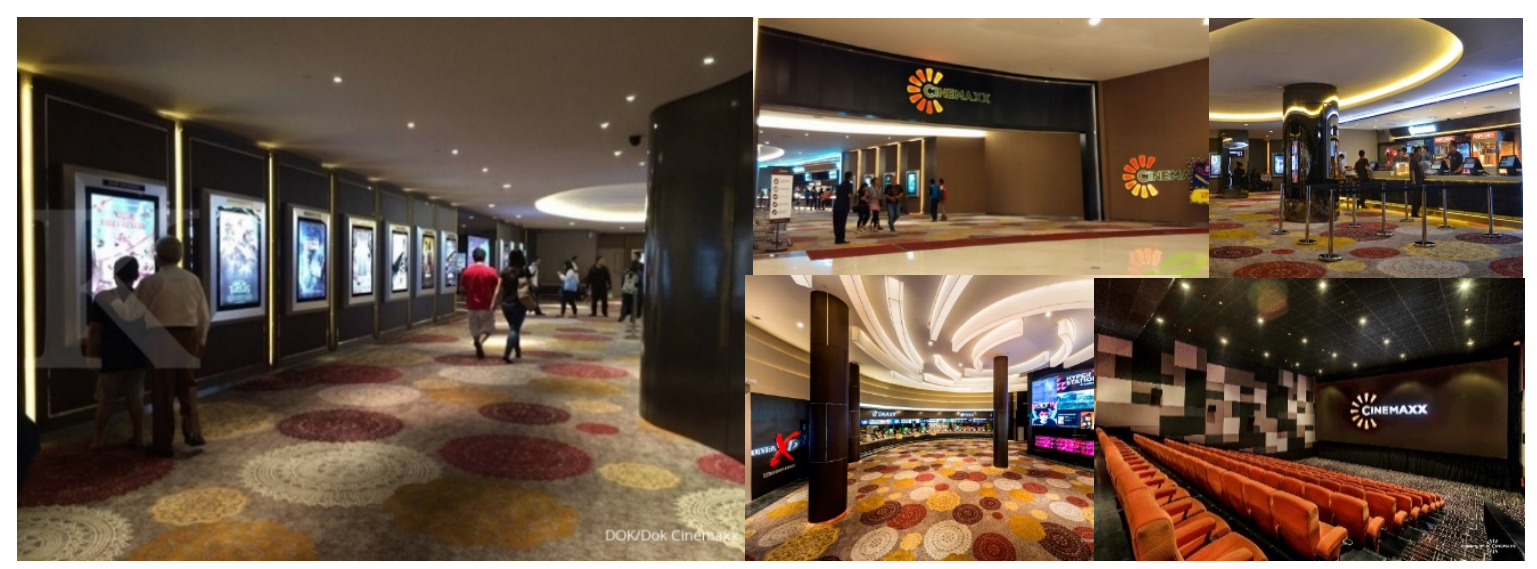

Gambar 3. Interior Cinemaxx

(sumber: diolah dari berbagai sumber) 

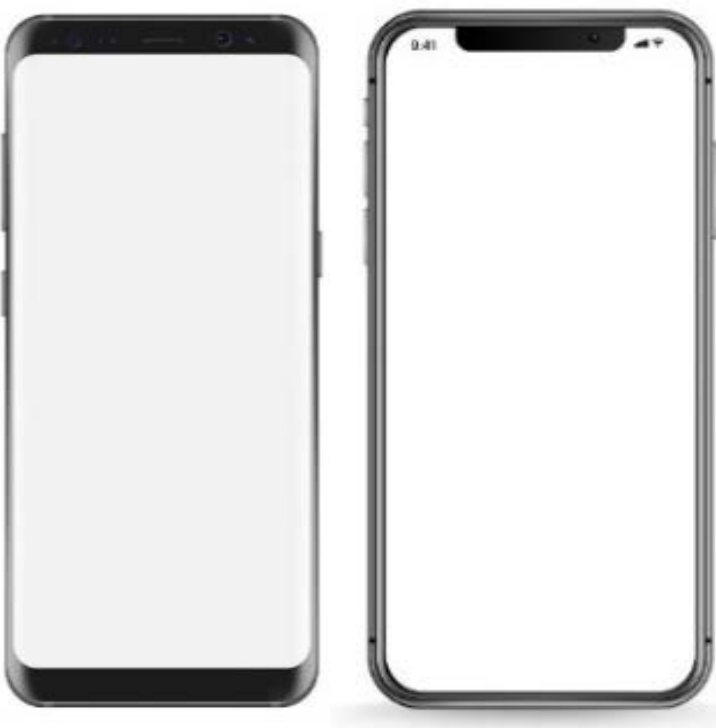

Gambar 4. Ponsel pintar (sumber: gsmarena.com)

Bidang-bidang tersebut merupakan bidang geometris yang disusun secara teratur dengan komposisi analog dengan gangguan pada beberapa bagian. (2) Sisi-sisi ruang terdiri dari massa yang masif dengan perulangan yang disusun secara beraturan. (3) Warna yang digunakan cenderung warna-warna gelap dan desaturated. Serta banyak aksen bidang warna hitam di berbagai sisi ruangan. (4) Beberapa bidang memiliki tekstur mengkilap, namun tetap didominasi oleh tekstur matte atau kasar. Dan (5) Memanfaatkan banyak ambient light sebagai hiasan utama pada interiornya, dengan penggunaan cahaya analog berwarna kuning yang memiliki intensitas tinggi ke rendah.
Sebagian besar masyarakat Indonesia kurang terbiasa menggunakan teknologi yang tergolong baru. Apalagi jika teknologi tersebut merupakan fasilitas umum yang diletakkan di tempat terbuka untuk umum. Ada kecenderungan sebagian masyarakat untuk takut menggunakannya. Untuk mengantisipasi hal ini, desainer perlu menghasilkan bentuk-bentuk yang familiar menurut pengguna, dan bentuk yang seakan-akan membolehkan seseorang untuk melakukan kesalahan. Untuk mencapai bentuk familiar tersebut, strategi yang digunakan adalah memanfaatkan bentuk-bentuk yang sangat sering digunakan oleh pengguna. Oleh karena itu desainer memilih smartphone sebagai acuan. Hal ini dilakukan dengan pertimbangan bahwa hampir semua orang memiliki smartphone dengan pola hubungan yang mirip dengan produk yang dirancang.

Strategi lain adalah dengan meniru orientasi layar saat digunakan pada posisi normal. Pada posisi normal, orang terbiasa memegang smartphone-nya dengan orientasi vertikal atau portrait. Strategi ini diharapkan dapat menghasilkan sebuah tampilan yang familiar menurut pengguna

Dari segi bisnis, Tritek merupakan industri yang jelas berbasis teknologi. Dalam dunia teknologi, kebaruan dan kecanggihan seakan-akan menjadi muka dari perusahaan tersebut. Strategi terhadap hal ini, untuk mewakili karakteristik dari industri tersebut, diperlukan image tritek yang hi-tech melalui peminjaman bentuk-bentuk yang up-to-date serta menghindari bentuk-bentuk yang dapat menciptakan kesan lampau bagi orang yang melihatnya. Capaian ini dilakukan dengan dengan upaya analisis formalistik pada produk-produk terkini yang dirasa dapat membawa kesan masa kini.
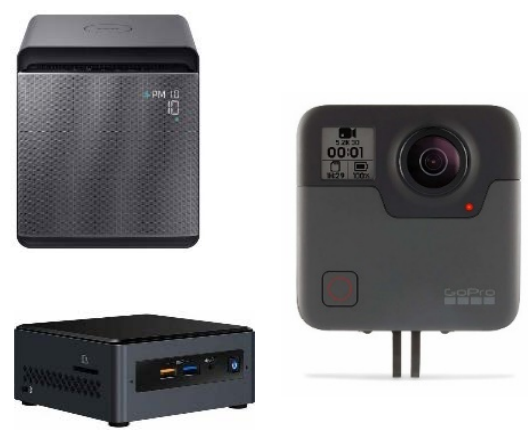
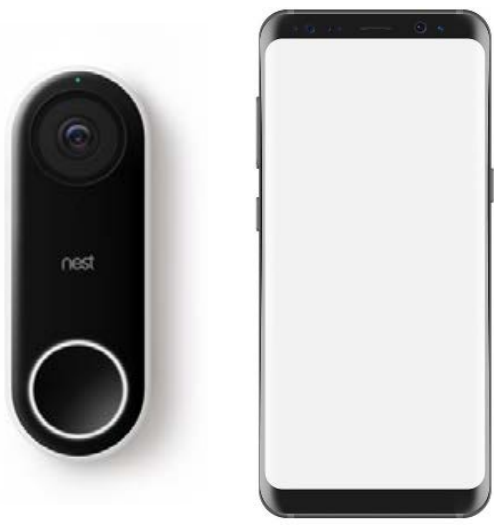

Gambar 5 Contoh produk terkini (sumber: diolah dari berbagai sumber) 


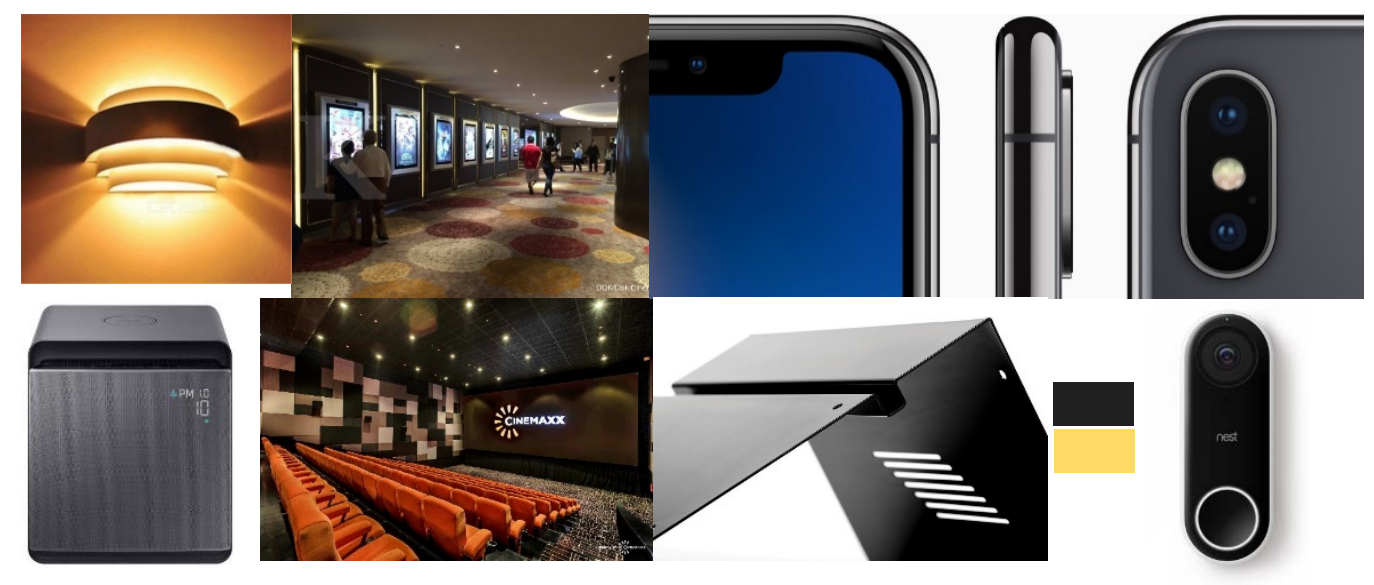

Gambar 6. Image Board

(sumber: diolah dari berbagai sumber)

Berdasarkan contoh pada Gambar 5 tersebut, dihasilkan beberapa penjabaran mengenai unsur visual dominan yang terdapat pada produk-produk tersebut, yaitu (1) terdiri dari bidang geometris yang terdiri dari garis-garis lurus dan memiliki sudut lengkung; (2) bidang-bidang tersebut disusun secara analog; (3) terdiri dari massa geometris yang bersifat masif; (4) didominasi warna logam dan hitam; dan (5) bertekstur dengan kombinasi matte dan mengkilap. Analisis tersebut menyimpulkan unsur yang dominan pada contoh-contoh produk yang diambil adalah bidang geometris yang memiliki sudut melengkung, serta warna yang digunakan adalah warna logam maupun hitam.

Melalui analisis tersebut maka dihasilkan karakteristik dari masing-masing aspek yang dijadikan sebagai bahan pertimbangan perancangan. Setiap hasil analisis memberikan karakteristik unsur visual yang dapat dijadikan bentuk yang mewakili tiap aspek tersebut.

Bentuk-bentuk tersebut menjadi dasar dari bentuk- bentuk yang dipinjam dan diimplementasikan kepada produk yang didesain.

Hasil analisis mengarahkan untuk adanya pertimbangan pemilihan komposisi visual hingga akhirnya dapat memberi bentuk yang menguntungkan. Salah satu perangkat yang digunakan untuk mempertimbangakn hal ini adalah dengan membuat image board dari citra yang telah disimpulkan. Dengan penggunaan image board diharapkan ekspresi visual dapat dimiliki agar dihasilkan alternatif kualitas visual yang diharapkan.

Kesimpulan yang diambil dari imageboard pada Gambar 6 tersebut dapat diuraikan sebagai berikut: (1) bentuk didominasi oleh bidang geometris yang disusun dari garis-garis lurus teratur dan memiliki sudut lengkung; (2) unsur-unsur visual dikomposisikan dengan komposisi analog; (3) didominasi warna hitam; (4) memiliki permukaan mengkilap dan matte; dan (5) menggunakan pencahayaan yang menghasilkan ambient lights berwarna kuning.

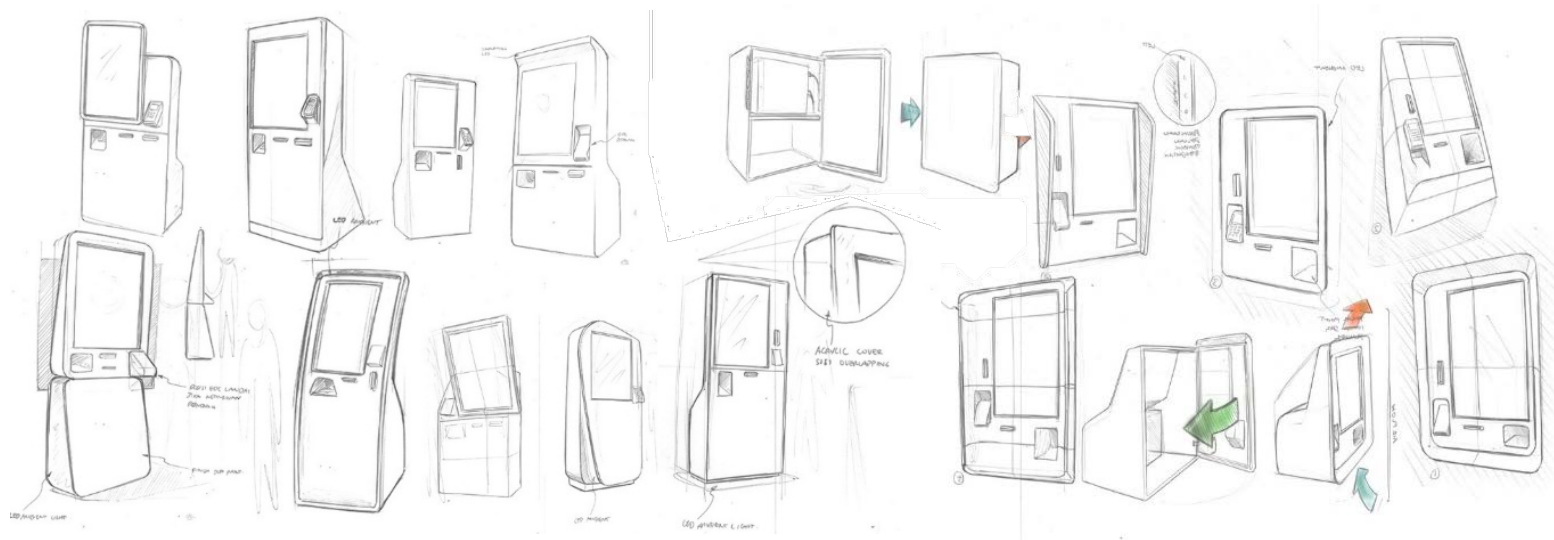

Gambar 7. Alternatif sketsa desain 
Rafi Ihsandiyumna \& Andry Masri

Keputusan bentuk visual dalam mendesain self service kiosk

Tabel 2. Ringkasan hasil diskusi alternatif desain

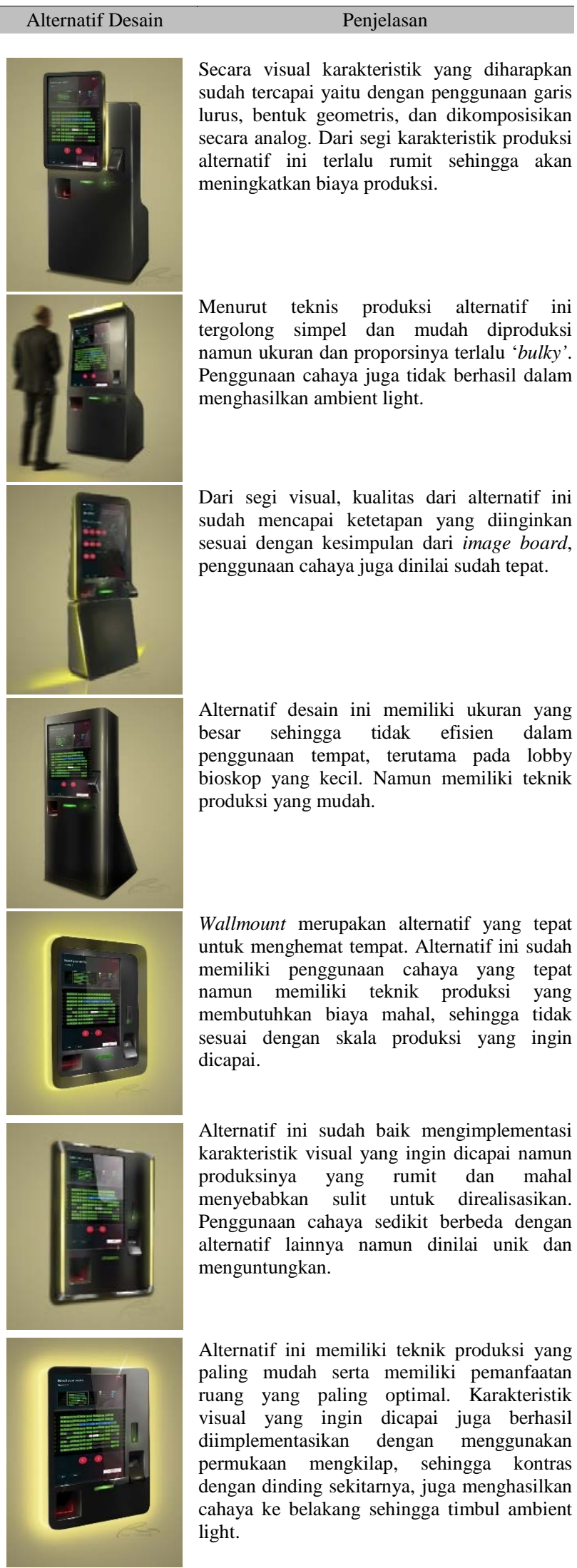

Ketetapan tersebut kemudian dijadikan sebagai acuan bentuk visual dalam menghasilkan alternatif desain. Seperti proses desain pada umumnya, alternatif desain dilakukan dengan metode sketsa. Sketsa dinilai dapat mempercepat proses menghasilkan ide bentuk sebab hanya menggunakan medium alat gambar dan media gambar. Kemudian, tiap sketsa yang telah dibuat dianalisis dengan pertimbangan faktor bentuk visual, ukuran, dan karakteristik produksi dan lainnya untuk mencapai suatu desain produk yang optimal.

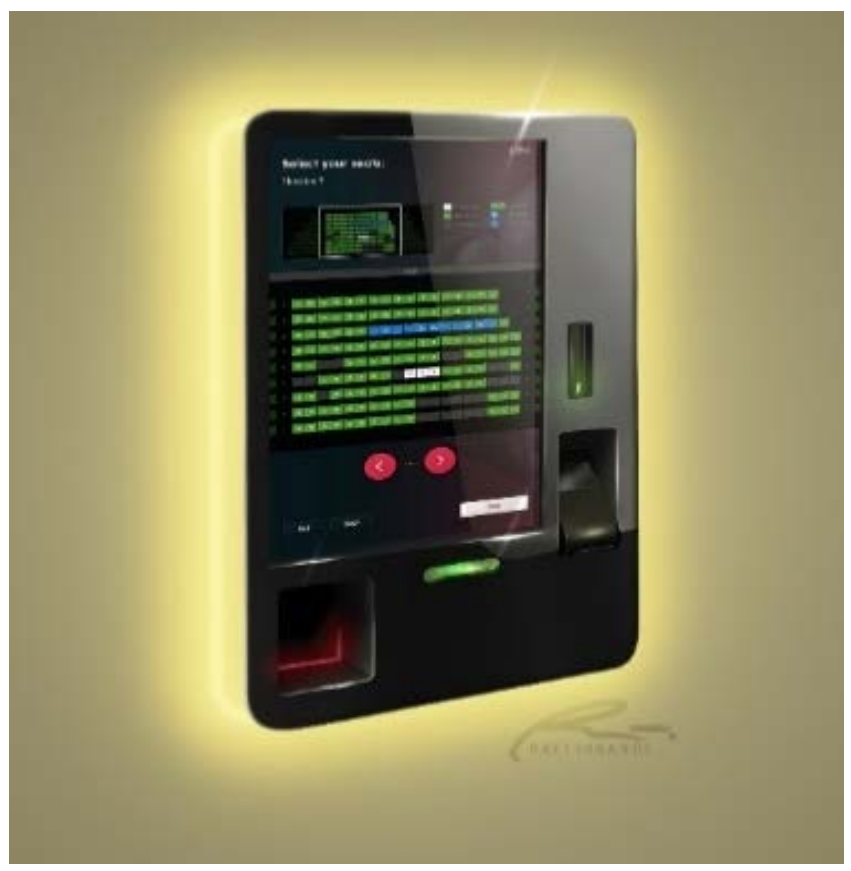

Gambar 8. Prelimenary design

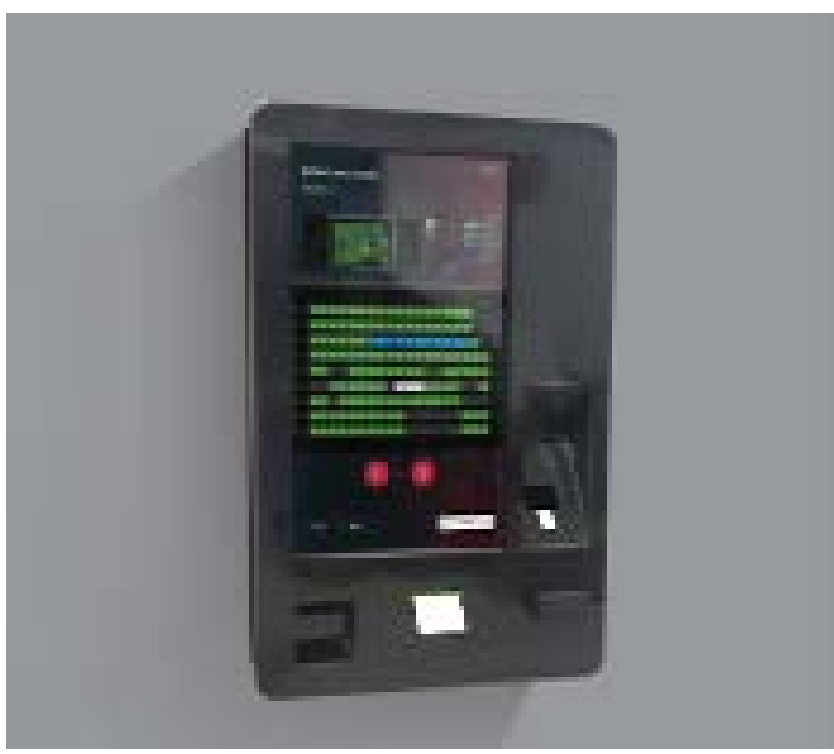

Gambar 9. Desain final produk 


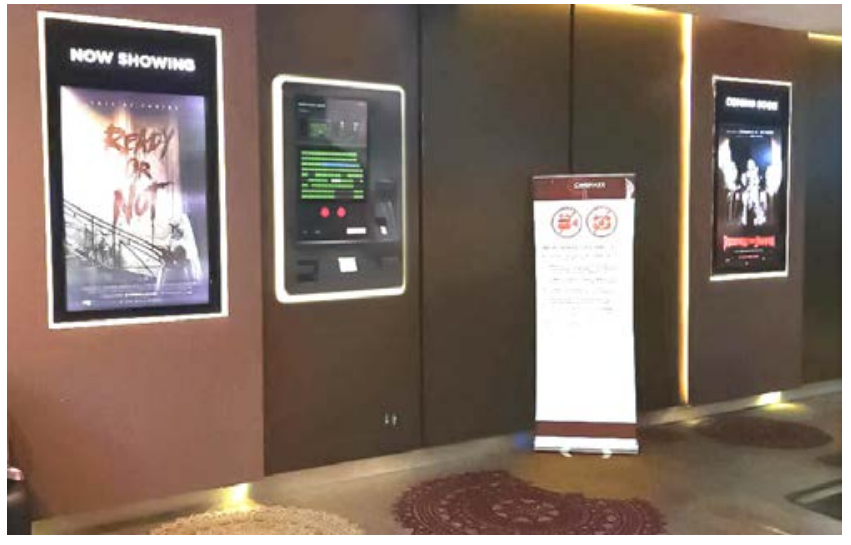

Gambar 10. Ilustrasi penempatan produk

Proses sketsa menghasilkan beberapa alternatif desain. Alternatif desain awal dipilih berdasarkan diskusi internal dengan industri produsen self-service kiosk yaitu Tritek sebagai pemberi tugas dari proyek ini. Beberapa hasil diskusi dengan Tritek sebagai pemberi tugas dirangkum dalam Tabel 2.

Ilustrasi pada Gambar 10 menunjukkan bagaimana produk saat diletakkan pada lokasi dan hubungannya dengan interior di Cinemaxx. Dapat dilihat bahwa bidang yang dipilih adalah persegi panjang sehingga terdapat kesatuan pada objek sekitarnya, ditambah warna hitam yang digunakan memberi keselarasan terhadap objek-objek yang berada di sampingnya. Penggunaan cahaya ke belakang selain menunjukan tercapainya image board juga mempertegas keberadaan produk tersebut.

\section{Kesimpulan}

Berdasarkan analisis dan uraian pembahasan di atas maka dapat diambil beberapa kesimpulan sebagai berikut: (1) Pendekatan formalistik dapat dilakukan untuk meningkatkan kesesuaian penggunaan produk dengan memanfaatkan image board suasana interior dimana produk akan ditempatkan, dan analisis formalistik terhadap produk yang sudah familiar dengan pengguna. (2) Pendekatan formalistik dapat digunakan untuk meminjam karakteristik visual sebuah objek kemudian diimplementasikan pada produk lainnya. (3) Karakteristik visual yang dimiliki sebuah objek dapat diolah kembali menjadi bentukbentuk yang baru tanpa meninggalkan karakteristik asalnya. (4) Produk yang diletakkan pada suatu tempat dapat menjadi selaras dengan melakukan pendekatan visual berdasarkan tempat tersebut.

\section{Daftar pustaka}

Curran, J. M., \& Meuter, M. L. (2005). Self-service technology adoption: comparing three technologies. Journal of Services Marketing, 19(2), 103-113.

De Noblet, J. (1993). Industrial design: reflection of a century. Paris: Flammarion/APC1.

Design Council. (2007). The Value of Design. Factfinder Report. London. Retrieved from https://www.designcouncil.org.uk/resources/report/factfi nder-value-design

Masri, A. (2010). Strategi Visual. Yogyakarta: Jalasutra. 